\title{
Making the most of your career
} Advice for new academic librarians

$\mathbf{L}$ ibrarianship has much to offer in terms of personal satisfaction and career opportunities. I enjoy the freedom, the challenges, and the opportunity to be a lifelong learner this career provides. However, with freedom comes responsibility and the knowledge that your future is in your hands. This can be a daunting realization, whether you are just beginning your career or have been working at it for a while.

When I started my job I was concerned with meeting the needs of patrons and building relationships across campus, while simultaneously managing the tenure-track process. If you are a new librarian you will understand me when I say that having the opportunity to be tenured comes with some measure of anxiety. With three semesters of work under my belt and the helpful advice of other librarians, I offer the following words of advice.

- Expect to enjoy your work. A recent article identified patron contact as a major factor in job satisfaction for reference librarians, and, as a result, they were among the most satisfied library employees with only those in supervisory roles happier. ${ }^{1}$

As a new librarian, I imagined that working at the desk would be my most challenging assignment. I wondered what kind of questions I might get and how I might flounder as I looked for information. I remember someone commenting that librarians were the living, breathing version of Google, and I knew I couldn't live up to that. What worked best to quell my fears was to try and find the answer myself before asking for help. This built my confidence and helped me see our resources from the patron's point of view. Some of the most challenging questions I have encountered are genealogy-related. If you can find an answer to these inquiries quickly, I encourage you to try. However, most genealogy questions require a considerable amount of research, and it's best to refer the person to the local historical society, state library, and public library for answers. After my initial jitters wore off, I found working at the reference desk to be some of the most rewarding work I do.

- Manage your time to the best of your abilities. Keeping a daily log will give you a sense of your accomplishments and a record that can help build your dossier. One major time challenge is committee work. Because so many library assignments are fun, you won't want to miss out on anything, it will be hard to refrain from joining every committee. However, you must refrain or you will begin to teeter on the edge of burnout.

As the new kid on the block, I felt the need to be involved in everything and was invited to be part of many teams and committees. Resist that urge. Join some, but protect your time and join only those that further your goals. As a note, I did not do this. I became the treasurer of the staff association, a committee member for the state academic library symposium, volunteered to serve on the teaching help desk, became a board member for the local Friends of the Public Library, volunteered to be a member of the

René Tanner is reference librarian at Montana State University, e-mail, rene.tanner@montana.edu (๑) 2010 René Tanner 
display committee, and served on the library faculty administration committee. A valuable lesson learned the hard way.

- Make the promotion and tenure process manageable. If you are at a land grant university, you are likely on the tenure track. Librarians have this opportunity at more than $60 \%$ of public institutions and for land grant institutions that figure climbs to $70 \%$, by contrast only $14 \%$ of private institutions offer tenure to librarians. ${ }^{2}$ If you are on the tenure track, it's important to read through the promotion and tenure document and understand your library's expectations, so you can begin to build your case. The best advice I received about building a paper trail of my merits was to set aside a drawer and toss things in as they came along. Evidence toward tenure can include unsolicited thank you letters from students, colleagues, and other faculty, as well as course syllabi and professional development activities.

Also, try to keep your CV up-to-date with trainings, presentations, and articles. I always breathe a sigh of relief after I update it, knowing that I'm not forgetting anything, and it's bound to make the process easier when it comes time to submit the dossier.

- Find a mentor early in the process.

Even before I started working at the university, I was invited to participate in a universitywide mentoring program. I was paired with a mentor from the Plant Sciences Department. As a result, I received one-on-one coaching, attended mentoring lunches, and met other new faculty members. The greatest benefit was to have someone to check in with and give updates to. In addition, our library has an informal mentoring program that has included group discussions about the promotion and tenure process, which has helped me understand the university's expectations. If your university doesn't have a formal mentoring program, find a senior librarian who is willing to act in this capacity. And remember that you'll have a chance to give back when you're senior faculty.

- Make time to write and think about

research. Look for opportunities to speak at conferences and to submit ideas for poster sessions. These are important contributions to your scholarship. Thus far, my librarianship has fed my research. For example, a workshop for library patrons turned into a conference presentation, and holding office hours outside the library provided material for a poster session. However, published articles carry the most weight, when it comes to promotion and tenure. ${ }^{3}$ To write an interesting paper you'll need to read widely. When I was in graduate school a PhD student gave me this advice, "Study other people's failed experiments and see if there is a new angle to take."

- Remember to network. Attending conferences is a great way to keep up on the latest trends and meet new people. I attended two conferences using my travel funds in my first year. These were great opportunities to connect with old friends and meet new people with similar interests. Great ideas for research come out of conferences. Most universities offer travel funds, but they may be limited. Try to get the most out of your travel funds by booking early and sharing housing. Many event organizers will coordinate roommates.

Librarianship has much to offer. As a new librarian many things will be asked of you. Be conscious of your time commitments. Seek a mentor early in the process to help you keep a healthy perspective of your accomplishments. Attend conferences to stay energized and connected with your peers. Enjoy your time at the reference desk-it's rewarding. And lastly, have fun and grow your career.

\section{Notes}

1. E. F. Topper, "Job satisfaction in libraries: Love it or leave it," New Library World 109, no. 5/6 (2008): 287-90.

2. Mary K. Bolin, "Librarian status at U.S. research universities; Extending the typology," Journal of Academic Librarianship 34, no. 5 (2008): 416-24.

3. Deborah B. Henry and Tina M. Neville, "Research, publication, service patterns of Florida academic librarians," Journal of Academic Librarianship 30, no. 6 (2004): 435-50. z 